Ana M. C. Rodrigues, Vítor Monteiro, Tiago J. C. Sousa, Tiago Alves, J. G. Pinto, João L. Afonso

"Advanced Load-Shift System: An Experimental Validation of the ac-dc Converter as Shunt Active Power Filter,"

EAI SESC International Conference on Sustainable Energy for Smart Cities, Braga, Portugal, Dec. 2019. 


\title{
Advanced Load-Shift System: An Experimental Validation of the ac-dc Converter as Shunt Active Power Filter
}

\author{
Ana M. C. Rodrigues ${ }^{1}$, Vítor Monteiro ${ }^{1}$, Tiago J. C. Sousa ${ }^{1}$, \\ Tiago Alves ${ }^{1}$, J. G. Pinto ${ }^{1}$, and João L. Afonso ${ }^{1}$ \\ ${ }^{1}$ ALGORITMI Research Centre, University of Minho, - Guimarães - Portugal \\ arodriguesedei.uminho.pt
}

\begin{abstract}
This paper presents a load-shift system with advanced functionalities to interface the power grid (PG). When compared with the conventional approach, an advanced load-shift system (aLSS) permits the compensation of power quality (PQ) problems for the grid-side, namely problems related to current harmonics, current imbalance, and power factor. The proposed aLSS is composed by a bidirectional ac-dc converter to interface the PG and by a bidirectional dc-dc converter to interface an energy storage system (ESS). Since the main innovation is related with the PG interface, the focus of this work is on the analysis of the ac-dc converter, which is based on a three-phase four-leg converter. A theoretical study and the details concerning the control algorithm are presented and discussed along the paper. A laboratory prototype of the proposed aLSS was developed and the details of implementation are described in the paper. Experimental results obtained with the developed prototype prove that the aLSS contributes for the technology progress in this area, validating a new concept of operation concerning the PQ on the PG side.
\end{abstract}

Keywords: Current Control, Three-Phase ac-dc Converter, Power Quality, advanced Load-Shift System, $p-q$ Theory.

\section{Introduction}

Nowadays, due to the climate change and global warming, there is a growing use of renewable energy sources. However, most of them have as main disadvantage the intermittence in the production of electric energy [1][2]. In this context, the concept of demand side management (DSM) using load-shifting systems comes up. This concept began to be studied some decades ago and consists in storing energy in periods of less demand and, posteriorly, use the stored energy in periods of higher demand [1]. The DSM is an important concept in smart grids and smart homes, since it allows the production and storage of energy in the same installation, allowing to take advantage of the energy price difference throughout the day, contributing for establishing a dynamic model of energy management [3]. Therefore, from the consumer perspective, an advanced load-shift system (aLSS) allows to reduce energy costs, since the consump- 
tion from the power grid $(\mathrm{PG})$ is minimized. Furthermore, it enables to reduce the contracted power to a lower grade by reducing the requirements of the power from the grid [4][5]. Nevertheless, despite the benefits of the introduction of an aLSS, the initial investment is high [6][7]. As aforementioned, from the PG point of view, the aLSS is seen as a system capable of consuming or producing power [5]. Therefore, it is extremely important an operation with high levels of power quality (PQ), i.e., with sinusoidal currents and high power factor (in three-phase systems, also with balanced currents), as demonstrated in [8], [9], [10] and [11]. Nevertheless, when it is not necessary to exchange power with the PG, the LSS is inactive, representing an opportunity to add new functionalities to the power converters. Moreover, such functionalities can be added also during the operation as LSS (i.e., when exchanging power with the PG). Therefore, this paper focuses on the experimental validation of the ac-dc converter of the LSS as a shunt active power filter (SAPF), which is the key differentiating factor when compared with the conventional approaches. With this functionality for the LSS, besides exchanging active power with the grid, the aLSS also allows to reduce the PQ degradation (as harmonic distortion of the current, current imbalance, and low power factor) [12][13][14]. In this way, the ac-dc converter of the LSS operates with the key characteristics of a SAPF [15][16][17][18]. It is important to note that the PQ problems must be solved, since, in the long term, they can cause malfunctions in sensitive equipment, causing a reduction in their life time and high monetary costs to the consumer. In the literature can be found several publications that present the three-phase four-leg voltage source converters for interface of renewable energy source with the PG and for SAPF applications [19][20][21].

This paper is organized as follows: Section 2 presents the proposed aLSS; Section 3 presents the proposed control algorithm; Section 4 presents the experimental validation; Section 5 presents the conclusions.

\section{Proposed advanced Load-Shift System (aLSS)}

Fig. 1 shows the structure of the proposed aLSS, which is composed by a bidirectional ac-dc converter to interface the PG with the dc-link, and by a bidirectional dc-dc converter to interface between the dc-link and the batteries, used as energy storage system (ESS). As mentioned in the introduction, the focus of this paper is the ac-dc converter, which is responsible for controlling the power consumption from the grid (active rectifier operation) or for controlling the power injection (inverter operation), in both cases with sinusoidal and balanced currents in the PG side. Regardless of whether the ac-dc converter is supplying power or not to the dc-dc converter, or injecting power into the PG, the ac-dc converter can be used to compensate current harmonics, current imbalance, neutral currents and for correcting the power factor of the electrical installation. 


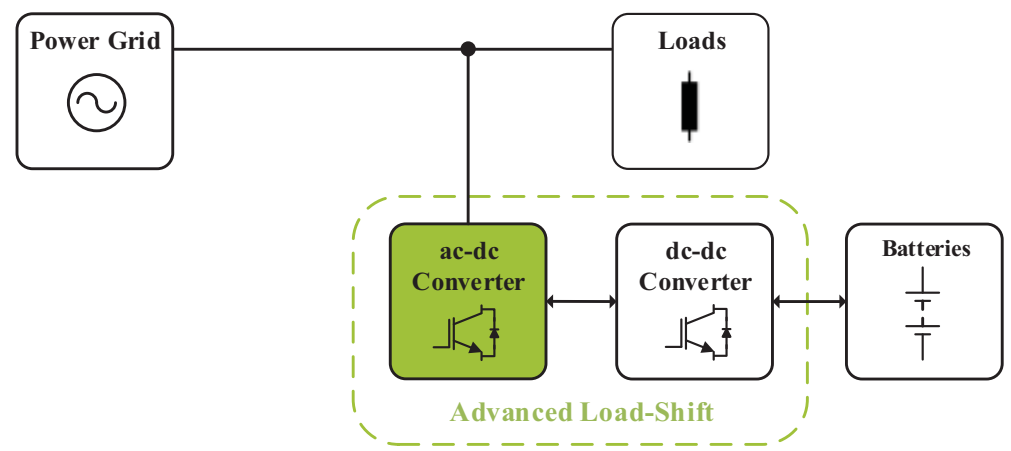

Fig. 1. Proposed structure for the advanced Load Shift System (aLSS).

The topology of the three-phase ac-dc converter used in the aLSS is presented in Fig. 2. As shown, the topology uses a three-phase four-leg voltage source ac-dc converter (in a total of eight switching devices, IGBTs in this case), and a dc-link formed by a capacitor (in fact, in the experimental validation, a set of capacitors were used in series). In the connection of the ac-dc converter with the PG, inductive coupling filters are used. Depending on the switching states assumed by the IGBTs, the converter can produce three voltage levels $\left(-v_{D C}, 0\right.$, and $\left.+v_{D C}\right)$.

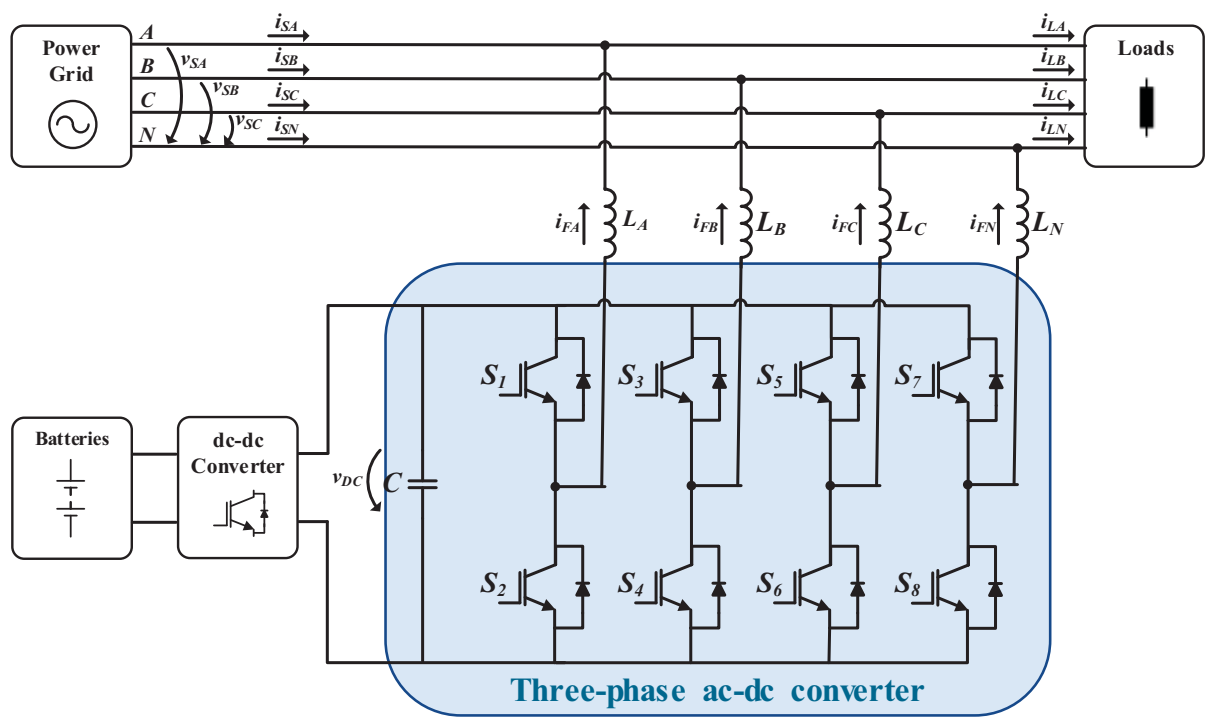

Fig. 2. Topology of the three-phase ac-dc converter used in the aLSS. 


\section{Proposed Control Algorithm}

The control algorithm of the ac-dc converter is mainly divided in three operation modes: (a) Operation as an active rectifier for consuming power from the grid; (b) Operation as an inverter for injecting power into the grid; (c) Operation as SAPF in both cases, i.e., in active rectifier or inverter mode. Fig. 3 shows the schematic of the proposed control algorithm. To calculate the reference currents, it is fundamental to use a phase-locked loop (PLL) to avoid the propagation of the harmonic distortion of the PG voltage into the currents [22]. Therefore, through the PG voltages $\left(v_{S A}, v_{S B}\right.$, $\left.v_{S C}\right)$, the unitary PLL signals are obtained $\left(v_{\text {pllA }}, v_{\text {pllB }}, v_{\text {pll }}\right)$. Moreover, it is necessary to regulate the dc-link voltage $\left(v_{D C}\right)$ to its reference $\left(v_{D C}{ }^{*}\right)$. For this purpose a PI controller is used to obtain the regulation power $\left(p_{\text {reg }}\right)$. This variable is multiplied by the PLL signals and the reference currents are obtained $\left(i_{\text {reg } A}{ }^{*}, i_{\text {reg }}{ }^{*}, i_{\text {reg }}{ }^{*}\right)$. When the ac-dc converter operates as SAPF, it is fundamental to calculate the compensation currents. For that, through the $p-q$ theory, using as input parameters the load currents $\left(i_{L A}, i_{L B}, i_{L C}\right)$ and the fundamental component of the PG voltages $\left(v_{p l l A}, v_{p l l B}, v_{p l l C}\right)$, are calculated the compensation currents $\left(i_{C A}{ }^{*}, i_{C B}{ }^{*}, i_{C C}{ }^{*}\right)$. Then, the reference currents $\left(i_{A}{ }^{*}, i_{B}{ }^{*}, i_{C}{ }^{*}, i_{N}{ }^{*}\right)$ are obtained by summing the regulation currents with the compensation currents. The neutral reference current $\left(i_{N}{ }^{*}\right)$ is obtained by the sum of the reference currents $\left(i_{A}{ }^{*}, i_{B}{ }^{*}, i_{C}{ }^{*}\right)$. In order to control the currents $\left(i_{F A}, i_{F B}, i_{F C}\right)$ according to the references $\left(i_{F A}{ }^{*}, i_{F B}{ }^{*}, i_{F C}{ }^{*}\right)$, a predictive current control is used. The output of the current control results in four reference voltages $\left(v_{C A}{ }^{*}, v_{C B}{ }^{*}, v_{C C}{ }^{*}, v_{C N}{ }^{*}\right)$ that are compared with a triangular carrier to obtain the pulse-width modulation (PWM) signals to be applied to the IGBTs.

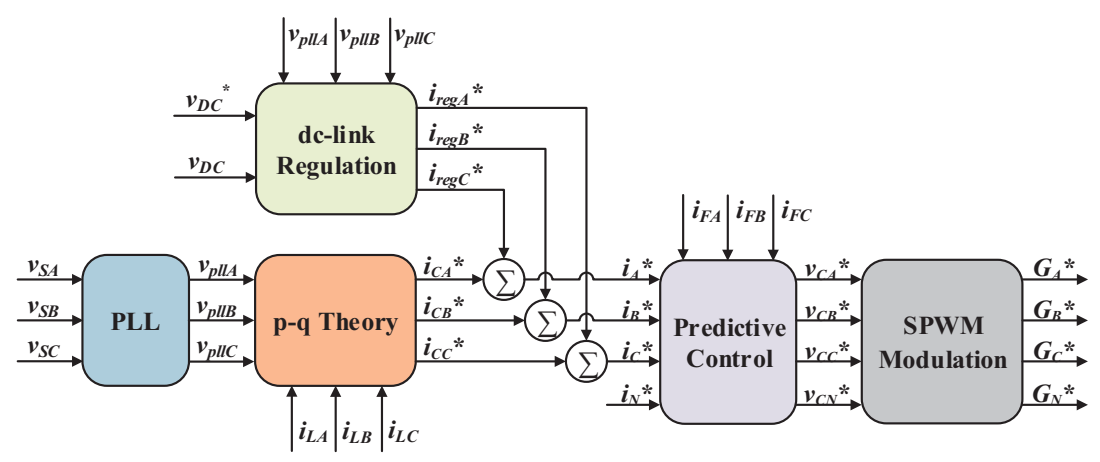

Fig. 3. Schematic of the control algorithm used in the aLSS.

\section{Experimental Validation}

This section presents the developed prototype and the main experimental results obtained to validate the proposed control strategy applied to the ac-dc converter of the aLSS when operating as: (a) Active rectifier; (b) Inverter; (c) SAPF. 


\subsection{Developed Prototype}

In this item, the developed prototype of the three-phase ac-dc converter of the aLSS is described in detail, which is divided in two parts: (a) Power stage circuit (including both the ac-dc and dc-dc converters); (b) Control system (based on a single platform for all the aLSS).

The developed power stage is formed by the ac-dc converter and by four inductive coupling filters for connecting the converter in parallel with the PG. The ac-dc converter is formed mainly by four IGBT modules (model SKM100GB176D from Semikron) with four gate protection boards, and by four IGBT gate drivers (model SKHI 22AH4R from Semikron) for actuating the IGBTs with a fixed switching frequency of $20 \mathrm{kHz}$ and a configured deadtime of $3.3 \mu \mathrm{s}$. The dc-link is composed by three capacitors (model B43456-A5568-M from EPCOS) connected in series, forming a total capacitance of $1867 \mu \mathrm{F}$ and a maximum voltage of $1350 \mathrm{~V}$.

Fig. 4 shows a block diagram of the developed control system divided into the signal acquisition circuits, the signal conditioning circuits, the signal processing circuits, and actuation circuits. Initially, the variables of the system are acquired, with a sampling frequency of $40 \mathrm{kHz}$, by voltage sensors (LV 25-P from LEM) and current sensors (LA 100-P from LEM). The acquired signals from the sensors are adapted to digital signals for being read by the digital signal processor (DSP) TMS320F28335 from Texas Instruments. This conversion is performed through an external analog-todigital converter circuit mounted in a signal conditioning board which also integrates an error detection circuit. Therefore, after implementing the control algorithms in the DSP, the PWM output signals are sent to the IGBT gate drivers through a command circuit for adapting the PWM signals to the $3.3 \mathrm{~V}$ TTL to $15 \mathrm{~V}$ CMOS logic required by the gate drivers.

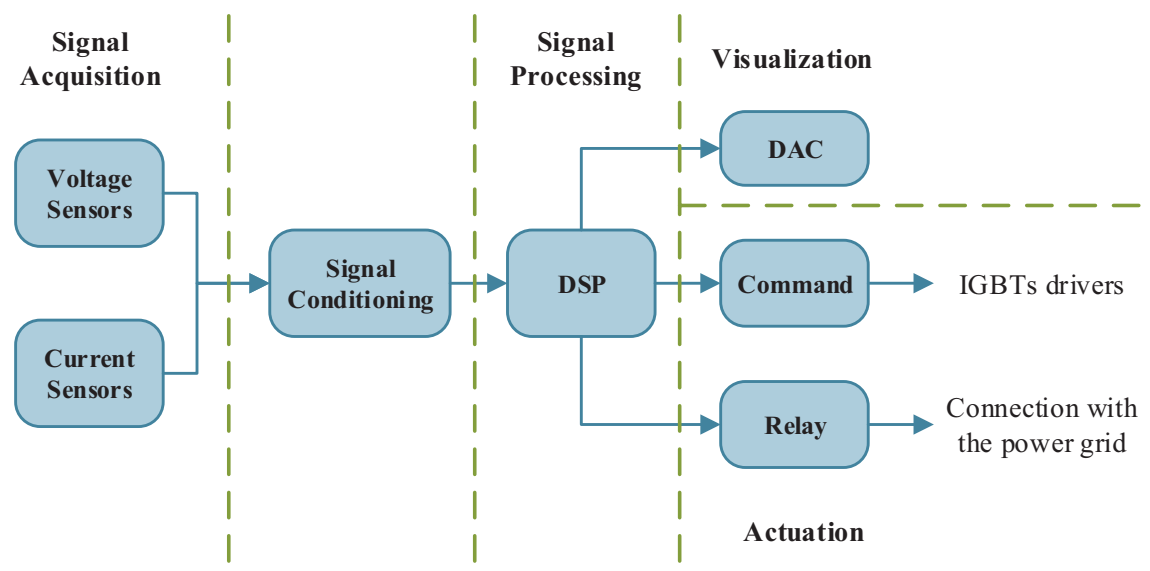

Fig. 4. Block diagram of the control system structure used in the aLSS. 
Fig. 5 shows the developed prototype of the aLSS integrated in the workbench used in the experimental setup, and Table 1 presents a summary of the main nominal characteristics of the ac-dc converter.

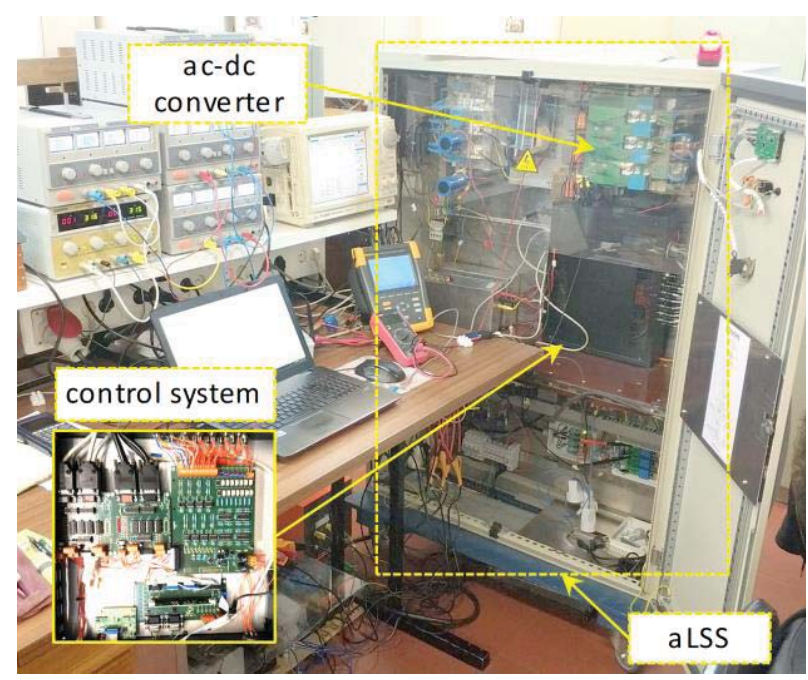

Fig. 5. Developed prototype of the aLSS integrated in the workbench.

Table 1. Nominal characteristics of the ac-dc converter.

\begin{tabular}{lc}
\hline Parameter & Value \\
\hline Power grid voltage (line-to-line) & $400 \mathrm{~V}$ \\
Nominal power $\left(S_{3}\right)$ & $13.8 \mathrm{kVA}$ \\
Nominal dc-link voltage $\left(v_{D C}\right)$ & $800 \mathrm{~V}$ \\
Switching frequency $\left(f_{s w}\right)$ & $20 \mathrm{kHz}$ \\
Sampling frequency $\left(f_{s}\right)$ & $40 \mathrm{kHz}$ \\
Coupling inductors $\left(L_{A}, L_{B}, L_{C}, L_{N}\right)$ & $2.4 \mathrm{mH}$ \\
Dc-link capacitor $(C)$ & $1.8 \mathrm{mF}$ \\
\hline
\end{tabular}

\subsection{Experimental Results}

This item shows the experimental results of the three-phase four-leg ac-dc converter operating in the three main modes: (a) Operation as an active rectifier for consuming power from PG; (b) Operation as an inverter for injecting power to the PG; (c) Operation as SAPF in both cases, i.e., in active rectifier or inverter mode. It is important to note that, for safety reasons, during the experimental validation the ac-dc converter was connected to the PG through a variable three-phase autotransformer followed by a 20:3 transformer, thus the line-to-line voltage of the PG is $100 \mathrm{~V}$. 


\section{Operation as Active Rectifier}

In this operation mode, a resistive load of $26 \Omega$ was connected in parallel with dc-link and the dc-link voltage was regulated to $200 \mathrm{~V}$. Fig. 6 shows the stages of the dc-link voltage regulation. In stage (1), the ac-dc converter is not connected to the PG, thus the dc-link voltage is $0 \mathrm{~V}$. In stage (2), the ac-dc converter is connected to the PG by pre-charge resistors. During this stage, the dc-link is charged to the peak voltage of the line-to-line PG voltage $(147 \mathrm{~V})$. Thereafter, in stage (3), the ac-dc converter is connected directly to the PG, and in stage (4) begins the dc-link voltage regulation to the reference average voltage $(200 \mathrm{~V})$. When the dc-link voltage stabilizes, the resistive load is connected to the dc-link and, as it can be seen, the dc-link voltage is set at $200 \mathrm{~V}$ (stage (5)).

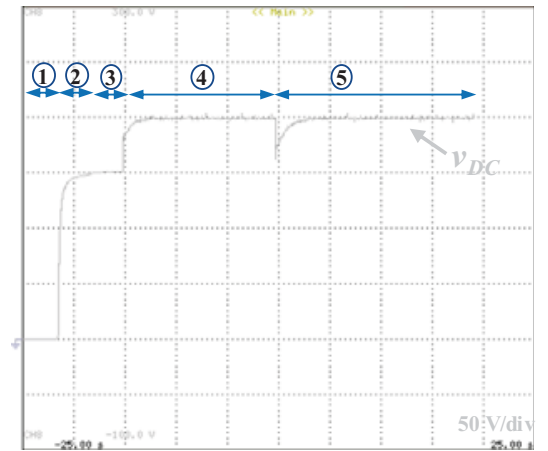

Fig. 6. Experimental results of the ac-dc converter operating as active rectifier during the dc-link voltage regulation: (1) ac-dc converter turned-off; (2) Pre-charge of the dc-link voltage; (3) Direct connection of the ac-dc converter to the PG; (4) dc-link voltage regulation to the defined reference; (5) Load connection.

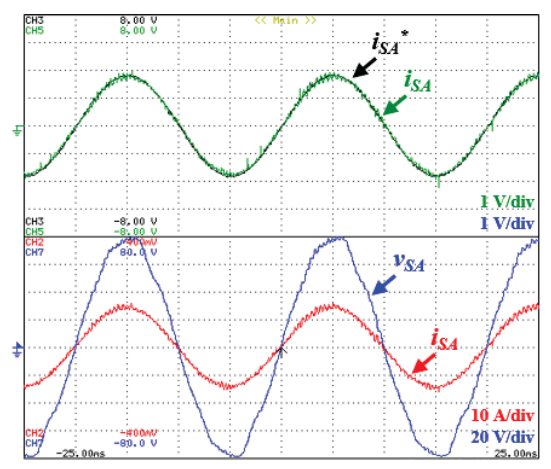

(a)

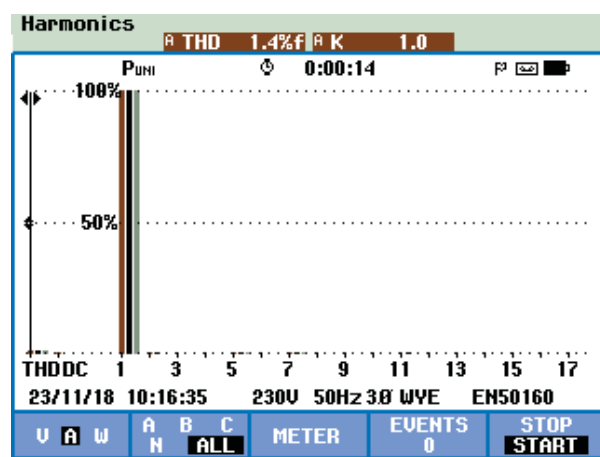

(b)

Fig. 7. Experimental results of the ac-dc converter operating as active rectifier: (a) Reference current $\left(i_{S A} *\right.$ ), voltage $\left(v_{S A}\right)$ and current $\left(i_{S A}\right)$ in phase $A$ of the PG; (b) Harmonic spectrum of the PG currents. 
Fig. 7 (a) presents, for phase $A$, the PG voltage $\left(v_{S A}\right)$ and the grid current $\left(i_{S A}\right)$ during stage (5). As can be seen, the PG current is sinusoidal and in phase with the PG voltage. On the other hand, it is possible to observe that the PG current $\left(i_{S A}\right)$ follows its reference current $\left(i_{S A}{ }^{*}\right)$. Fig. 7 (b) shows the harmonic spectrum of the PG currents $\left(i_{S A}, i_{S B}, i_{S C}\right)$, with a total harmonic distortion $\left(\mathrm{THD}_{\%}\right)$ of $1.4 \%$.

\section{Operation as Inverter}

For the operation mode as inverter, the dc-link was powered by a power supply of $300 \mathrm{~V}$ and it was defined for the PG currents a sinusoidal reference current with RMS value of $5 \mathrm{~A}$. The results of this experimental test are shown in Fig. 8. As it can be seen in Fig. 8 (a), the PG currents $\left(i_{S A}, i_{S B}, i_{S C}\right)$ are sinusoidal with a peak value of $7 \mathrm{~A}$ and in phase opposition with the PG voltages $\left(v_{S A}, v_{S B}, v_{S C}\right)$, meaning that the ac-dc converter is injecting energy into the PG. Moreover, as Fig. 8. (b) shows, the produced currents in the PG $\left(i_{S A}, i_{S B}, i_{S C}\right)$ present a $\mathrm{THD}_{\%}$ of $2.6 \%$.

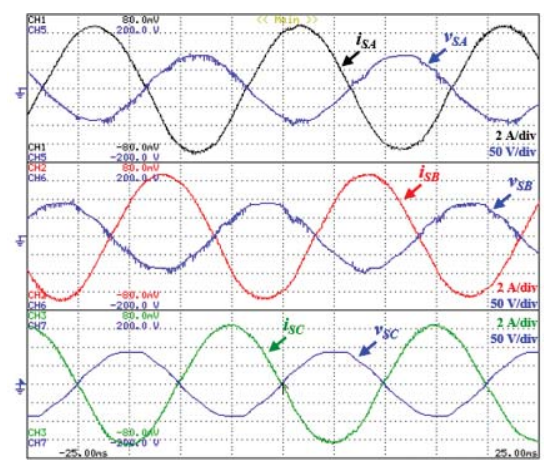

(a)

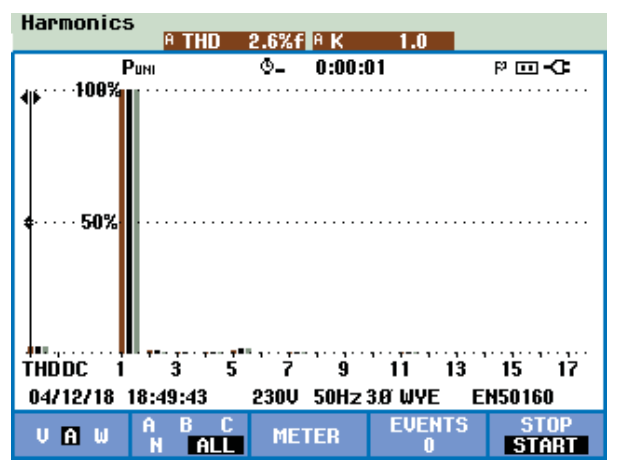

(b)

Fig. 8. Experimental results of the ac-dc converter operating as inverter: (a) PG voltages ( $v_{S A}$, $\left.v_{S B}, v_{S C}\right)$ and currents $\left(i_{S A}, i_{S B}, i_{S C}\right)$; (b) Harmonic spectrum of the PG currents.

\section{Operation as SAPF}

In the operation mode as SAPF, the dc-link voltage was regulated to $400 \mathrm{~V}$ and some loads were connected to the PG. As can be seen in Fig. 9 (a), the currents consumed by the loads $\left(i_{L A}, i_{L B}, i_{L C}, i_{L N}\right)$ contain a high harmonic component with a $\mathrm{THD}_{\%}$ of $76.8 \%$ (Fig. 9 (b)) and a low power factor. Moreover, the load currents are imbalanced, leading to a high neutral current.

In other to compensate the PQ problems caused by the loads connected to the PG, the SAPF produces the compensation currents $\left(i_{F A}, i_{F B}, i_{F C}, i_{F N}\right)$ presented in Fig. 10. Fig. 11 shows the PG voltages $\left(v_{S A}, v_{S B}, v_{S C}\right)$ and currents $\left(i_{S A}, i_{S B}, i_{S C}, i_{S N}\right)$ after the compensation, where it can be seen that the currents are approximately sinusoidal, balanced and in phase with the correspondent voltages. On the other hand, through the harmonic spectrum analysis of the PG currents, it can be observed that the THD\% is reduced from $76.4 \%$ to $6.4 \%$ (Fig. 11 (b)). 


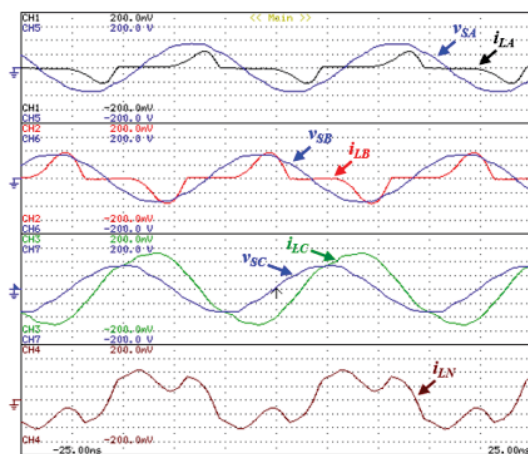

(a)

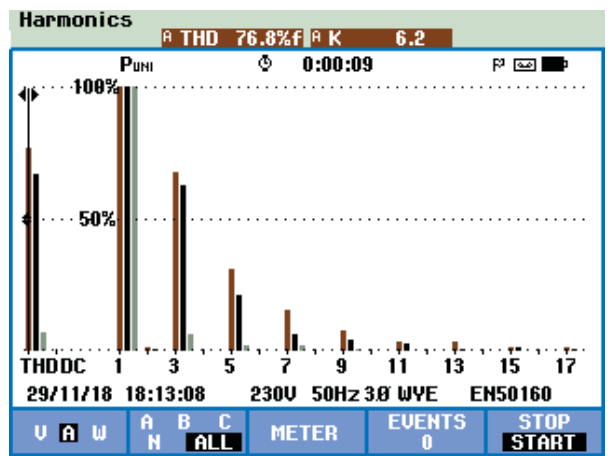

(b)

Fig. 9. Experimental results of the ac-dc converter operating as SAPF before compensation: (a) PG voltages $\left(v_{S A}, v_{S B}, v_{S C}\right)$ and load currents $\left(i_{L A}, i_{L B}, i_{L C}, i_{L N}\right)$; (b) Harmonic spectrum of the load currents.

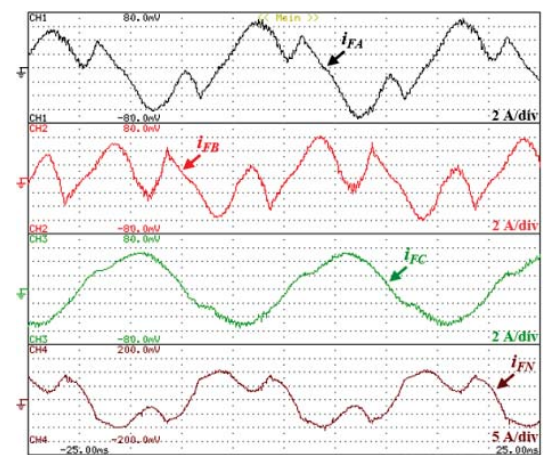

Fig. 10. Experimental results of the ac-dc converter operating as SAPF: Compensation currents $\left(i_{F A}, i_{F B}, i_{F C}, i_{F N}\right)$.

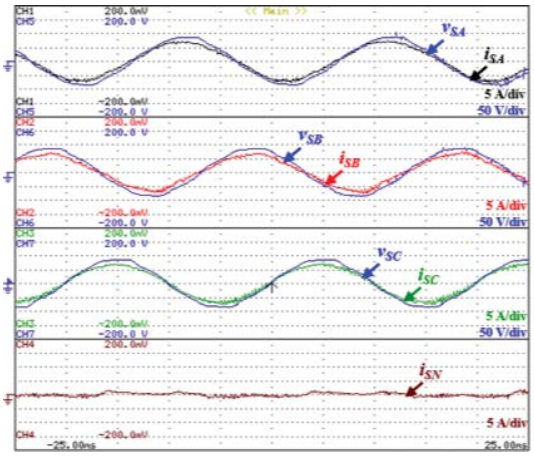

(a)

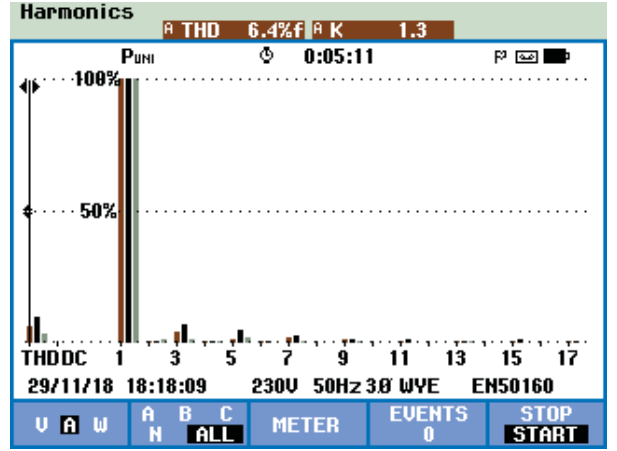

(b)

Fig. 11. Experimental results of the ac-dc converter operating as SAPF after compensation: (a) PG voltages $\left(v_{S A}, v_{S B}, v_{S C}\right)$ and currents $\left(i_{S A}, i_{S B}, i_{S C}, i_{S N}\right)$; (b) Harmonic spectrum of the PG currents. 


\section{Conclusions}

This paper presents an ac-dc converter of an advanced Load-Shift System (aLSS), which is responsible for charging the storage system (batteries) or injecting energy in the power grid (PG) with sinusoidal currents. On the other hand, when the load-shift system is operating as shunt active power filter, it is responsible for compensating the harmonics and balance of the currents, and the power factor of the electrical installation. Throughout this paper was described the proposed topology of the three-phase four-leg ac-dc converter, as well as its control algorithms, where are detailed the synchronization system with the $\mathrm{PG}$, the $p-q$ theory, the predictive current control and the sinusoidal pulse width modulation. An experimental validation was performed in order to validate the developed prototype operating as active rectifier, inverter and SAPF. The presented experimental results validate the implemented control algorithms, showing that for the operation mode as active rectifier, the absorbed currents in the PG are sinusoidal and balanced with unitary power factor. When the ac-dc converter operates as inverter the produced currents in PG are sinusoidal in phase opposition with correspondent voltages. In the operation as SAPF, the PG currents are approximately sinusoidal with a low total harmonic distortion.

\section{Acknowledgment}

This work has been supported by FCT - Fundação para a Ciência e Tecnologia within the Project Scope: UID/CEC/00319/2019. This work has been supported by the FCT Project QUALITY4POWER PTDC/EEI-EEE/28813/2017, and by the FCT Project newERA4GRIDs PTDC/EEI-EEE/30283/2017.

\section{References}

1. W. S. Ho, H. Hashim, J. S. Lim, and J. J. Klemeš, "Combined design and load shifting for distributed energy system," vol. 15, no. 3, pp. 433-444, 2013.

2. K. S. Reddy, M. Kumar, T. K. Mallick, H. Sharon, and S. Lokeswaran, "A review of Integration, Control, Communication and Metering (ICCM) of renewable energy based smart grid," Renew. Sustain. Energy Rev., vol. 38, pp. 180-192, 2014, DOI: 10.1016/j.rser.2014.05.049, ISBN: 1364-0321, ISSN: 13640321.

3. V. C. Gungor et al., "Smart grid and smart homes: key players and pilot projects," IEEE Ind. Electron. Mag., vol. 6, no. 4, pp. 18-34, 2012, ISSN: 1932-4529.

4. ERSE - Entidade Reguladora dos Serviços Energéticos, "Regulamento de Relações Comerciais do setor elétrico," 2017.

5. L. Dusonchet, M. G. Ippolito, E. Telaretti, G. Zizzo, and G. Graditi, "An optimal operating strategy for combined RES-based generators and electric storage systems for load shifting applications," Int. Conf. Power Eng. Energy Electr. Drives, vol. 5, pp. 552-557, 2013, DOI: 10.1109/PowerEng.2013.6635668, ISBN: 9781467363921, ISSN: 21555516.

6. Leonardo-Energy, Electric Load Management in Industry, no. January. 2009, ISBN: 2950787886 . 
7. T. Capiau and L. Van Daele, "Application note - Load Management of Industrial Systems," p. 30, 2016.

8. B.-M. Han, "Grid-tied Power Converter for Battery Energy Storage Composed of 2-stage DC-DC converter," J. Electr. Eng. Technol., vol. 8, no. 6, pp. 1400-1408, 2013, DOI: 10.5370/JEET.2013.8.6.1400, ISBN: 9781479913039, ISSN: 19750102.

9. J. G. Pinto, Vitor Monteiro, and B. Exposto, "Power Electronics Converters for an Electric Vehicle Fast Charging Station with Storage Capability,” vol. 1, pp. 119-130, 2012, DOI: 10.2174/97816080528511120101, ISBN: 9781608052851.

10. Vitor Monteiro, J. G. Pinto, and J. L. Afonso, "Experimental Validation of a Three-Port Integrated Topology to Interface Electric Vehicles and Renewables with the Electrical Grid," IEEE Trans. Ind. Informatics, vol. 14, no. 6, pp. 2364-2374, 2018, DOI: 10.1109/TII.2018.2818174, ISSN: 15513203.

11. J. G. Pinto, Vitor Monteiro; Goncalves, Henrique; Exposto, Bru, "Bidirectional Battery Charger with Grid-to-Vehicle, Vehicle-to-Grid and Vehicle-to-Home Technologies," 39th Annu. Conf. IEEE Ind. Electron. Soc. - Vienna, pp. 5932-5937, 2013, ISBN: 9781479902231.

12. J. S. Subjak and J. S. McQuilkin, "Harmonics -- Causes, effects, measurements, and analysis: An update," IEEE Trans. Ind. Appl., vol. 26, no. 6, pp. 1034-1042, 1990.

13. J. L. Afonso and J. S. Martins, "Qualidade da energia eléctrica," Rev. o Electr., pp. 66-71, 2005, ISSN: 0874-9019.

14. L. Cividino, "Power Factor, Harmonic distortion; Causes Effects and Considerations," in 14th International Telecommunications Energy Conference, 1992, pp. 1-7.

15. S. M. Halpin, "Power Quality Tutorial," no. November, 2008.

16. J. L. Afonso, J. G. Pinto, and H. Gonçalves, "Active Power Conditioners to Mitigate Power Quality Problems in Industrial Facilities," 2013, DOI: 10.5772/53189.

17. J. S. Martins, C. Couto, and J. L. Afonso, "Qualidade de energia eléctrica," $3^{\circ}$ Congr. Luso-Moçambicano Eng. - CLME'2003 Eng. e Inovação para o Desenvolv., pp. 219-231, 2003.

18. P. Neves, D. Gonçalves, J. G. Pinto, R. Alves, and J. L. Afonso, "Single-Phase Shunt Active Filter Interfacing Renewable Energy Sources with the Power Grid," IEEE Conf., no. November, pp. 3264-3269, 2009, ISBN: 9781424446490.

19. J. De Kooning, B. Meersman, T. Vandoorn, B. Renders, and L. Vandevelde, "Comparison of three-phase four-wire converters for distributed generation," Univ. Power Eng. Conf. (UPEC), 2010 45th Int., pp. 1-6, 2010, ISBN: 9780956557025.

20. J. G. Pinto, R. Pregitzer, L. F. C. Monteiro, and J. L. Afonso, "3-Phase 4-Wire Shunt Active Power Filter with Renewable Energy Interface Key words," ICREPQ'07-Int. Conf. Renew. Energies Power Qual., no. 1, pp. 28-30, 2007, ISBN: 9788461147076.

21. R. Pregitzer, J. Costa, J. Martins, and J. Afonso, "Filtro activo paralelo com interface entre fontes de energia renovável e a rede eléctrica," Conferência Int. sobre Energias Renov., pp. 89-94, 2006, ISBN: 9789728822071

22. L. G. Barbosa Rolim, D. Rodrigues da Costa, and M. Aredes, "Analysis and Software Implementation of a Robust Synchronizing PLL Circuit Based on the pq Theory," IEEE Trans. Ind. Electron., vol. 53, no. 6, pp. 1919-1926, Dec. 2006, DOI: 10.1109/TIE.2006.885483, ISSN: 0278-0046. 